\title{
Correction to: Revisiting Accounts of Narrative Explanation in the Sciences: Some Clarifications from Contemporary Argumentation Theory
}

\section{Paula Olmos ${ }^{1}$}

Published online: 9 March 2020

(c) Springer Nature B.V. 2020

\section{Correction to: Argumentation}

https://doi.org/10.1007/s10503-020-09511-5

In the original publication of this article, the acknowledgement section has been missed to publish. Now the same has been provided in this correction.

Acknowledgements This work has been made possible by funds provided by the Spanish Ministry of Science, Innovation and Universities through the Research Project Proyecto PGC 2018-095941B-100, "Argumentative Practices and the Pragmatics of Reasons".

Publisher's Note Springer Nature remains neutral with regard to jurisdictional claims in published maps and institutional affiliations.

The original article can be found online at https://doi.org/10.1007/s10503-020-09511-5.

\section{Paula Olmos}

paula.olmos@uam.es

1 Universidad Autónoma de Madrid, Madrid, Spain 